\title{
Evelyne Sanchez, Las élites empresariales y la independencia económica de México. Estevan de Antuñano o las vicisitudes del fundador de la industria textil moderna (1792-1847), Puebla, Benemérita Universidad Autónoma de Puebla / Fundación Miguel Alemán, A.C. / Plaza y Valdés, 2013, 363 pp.
}

\author{
Daniela Marino*
}

16 de mayo de 2017

\begin{abstract}
$\mathrm{E}^{\mathrm{L}}$ L libro que se reseñará a continuación se originó de la tesis doctoral que la autora presentó en la Universidad de Toulouse-Le Mirail, en el año de 2004. Pese a la fecha de edición, apenas en 2015 apareció en librerías, con lo cual la espera del estudio definitivo sobre Estevan de Antuñano y los orígenes de la industria textil en México se prolongó más de una década. Fuera de este y otros detalles (la tapa no incluyó el subtítulo, con lo cual, para un posible comprador en librería, el solo título dificulta ubicar a primera vista el objeto de estudio del libro, mientras que en bibliotecas dependerá del buen oficio de los catalogadores) la edición ha sido cuidada, en un formato usual y manejable. La imagen de tapa es un retrato poco conocido del protagonista, cuyos derechos los facilitaron sus descendientes.

Decíamos que esta es una investigación fundamental sobre Antuñano y, como puede advertirse desde el título, su contenido no es sólo biográfico. Es la historia de un individuo excepcional, pero también es la historia de una familia y una historia de élites. Encontraremos en este libro frecuentes referencias al estado de Puebla, y la república mexicana en la primera mitad del siglo XIX, su
\end{abstract}

*Escuela Nacional de Antropología e Historia, México. 
difícil contexto político y los problemas que esta situación acarreaba a la toma de decisiones en materia económica. Incluye un análisis sobre el debate entre librecambistas y proteccionistas, además del arranque de la actividad industrial en México; asimismo argumenta acerca de la continuidad de las sociabilidades del antiguo régimen en un marco de normas cambiantes y sobre la historiografía en torno al surgimiento de un empresariado moderno e individualista.

Desde un punto de vista metodológico, el libro de Evelyne Sanchez tampoco es una biografía tradicional, pues incluye importante información, hasta ahora desconocida, sobre Antuñano, sus ascendientes y descendientes, familia política, socios y vínculos empresariales y políticos. Tampoco es un estudio puro de $m i$ crostoria (aunque La herencia inmaterial, de Giovanni Levi, es una referencia recurrente para explicar algunas de sus más importantes elecciones metodológicas), ni exclusivamente un trabajo de redes (no obstante se declara discípula de Michel Bertrand, su asesor de tesis). El libro de Evelyne Sanchez es una magistral combinación de todos los elementos anteriores. Vale la pena leer con detenimiento la Introducción, donde explicita la definición de su objeto de estudio, la amplia variedad y cantidad de fuentes utilizadas y las decisiones teóricas y metodológicas que tomó para concretar su análisis. En particular, el uso del concepto y metodología de red para efectuar los cambios de escala, de la microhistoria del personaje a la prosopografía sociológica. Sin duda, además de la utilidad de su investigación para los historiadores que trabajan el periodo y el tema aquí tratados, la exposición de los andamios historiográficos con los que construyó su obra la convierten en una excelente opción didáctica para estudiantes de grado y posgrado.

El libro se estructura en cuatro partes, cada una compuesta de dos capítulos. La primera parte, "Estevan de Antuñano en 1847: ¿Una herencia inmaterial?”, apela a la historia regresiva para comenzar por el final de la biografía de Antuñano. Así, en el primer capítulo Sanchez escudriña, de manera retrospectiva, la construcción de la imagen de Antuñano como pionero de la industria textil en Puebla y como prototipo del empresario moderno, arriesgado e individualista, representación que comienza a elaborar él mismo en los últimos años de su vida como legado inmaterial y simbólico para sus descendientes. No obstante, es de manera póstuma que adquirió la categoría de mito, desarrollado tanto por la élite política poblana (que no siempre estuvo dispuesta a ayudarlo cuando lo necesitó) como por los empresarios industriales poblanos (quienes tampoco le habían sido siempre favorables). Una vez puesta en evidencia esta construcción -historiográfica, pero sobre todo política- de la figura de don Estevan, ${ }^{1}$ acto seguido la derrumba, en el capítulo dos, al confrontarnos con la realidad de sus últimos años de vida: el endeudamiento, la quiebra y la posterior pérdida de la fábrica La Constancia

\footnotetext{
${ }^{1}$ Tres de estos textos están reproducidos en el anexo uno.
} 
Mexicana por su familia. Llega a este punto al reconstruir, vía fuentes notariales, su patrimonio material y, por medio del análisis de su correspondencia particular, su red de relaciones personales y/o empresariales.

Como lectores, el evidente contraste entre estas dos imágenes de Estevan de Antuñano (el mito versus la realidad, el éxito y la ruina) nos deja en evidencia lo poco que en realidad se sabía sobre el personaje, y no hace sino incrementar nuestro interés por conocer más a fondo su vida personal, el desarrollo de sus negocios y las razones de su apuesta todo o nada por la industrialización, en vez de la entonces habitual diversificación de actividades económicas. Estos temas los analiza Sanchez en las restantes tres partes, seguidas de un epílogo, conclusiones y tres anexos.

La segunda parte, "Los recursos familiares o el fin del mito del self made man", está dedicada a determinar los recursos familiares que pudo haber heredado el futuro industrial (en el capítulo tres), al estudiar a los Antuñano de Veracruz (donde había llegado su padre, tal vez una década antes del nacimiento de Estevan, en 1792) y a los de Vizcaya (región española de la que era originaria su familia paterna), y los recursos que adquiriría en los años de 1820 mediante su inserción en la sociedad poblana a través del casamiento con Bárbara de Ábalos y Varela, la hija de una importante (tal vez con más alcurnia que riqueza) familia hacendada de Atlixco. Precisamente su suegro se convertiría en su principal apoyo e impulsor de su aventura industrial. ${ }^{2}$ De ambos capítulos, el cuarto es el más logrado, sin duda por la mayor cantidad y calidad de fuentes encontradas en los archivos poblanos y capitalinos referidos a su etapa industrial. No obstante, no está de más remarcar la impresionante prospección de archivos oficiales, notariales y eclesiásticos realizada por la autora en Puebla, Veracruz, Ciudad de México, Madrid, Segovia, Simancas, Bilbao y Guernica, además de varios periódicos mexicanos decimonónicos y más de trescientas cartas de la correspondencia privada de Antuñano (clasificadas en el anexo dos), en poder de su familia.

La tercera parte del libro, "La industria textil en Puebla. ¿Una oportunidad de movilidad social?", está dedicada a analizar la industria textil poblana: en el capítulo cinco, el contexto político y social en el que se instalan las fábricas, que permitieron, según la más reciente historiografía, el despegue textil temprano, así como las características del apoyo gubernamental y su red empresarial. Por otra parte, el capítulo seis es un estudio de la obra escrita de nuestro personaje, en el que se analizan sus referencias culturales e ideologías política y económica, lo que le permite a Sanchez establecer los autores que cita y aún la deficiente, por superficial, lectura de los mismos. Y, finalmente, establecer su posición pragmática entre liberalismo y conservadurismo, así como su nacionalismo económico.

\footnotetext{
${ }^{2}$ Sus socios y las relaciones obtenidas del análisis de libranzas, fianzas y poderes notariales están graficadas en el anexo 2 bis.
} 
La cuarta y última parte del libro, titulada "Resistencias y estrategias de oposición", está dedicada a las dificultades que encontró don Estevan para el éxito de su empresa: en el capítulo siete, los obstáculos estructurales y coyunturales de la primera mitad del siglo XIX mexicano, y en el capítulo ocho se construye una historia social de la oposición de los tejedores artesanales a la industria, así como de la rivalidad entre los industriales. Finalmente, el epílogo está dedicado a la lucha legal que siguieron sus herederos contra el principal acreedor de Antuñano, Pedro Bergés de Zúñiga, para mantener en sus manos La Constancia Mexicana, objetivo que no lograron.

Pero más allá de la obligada segmentación temática en capítulos, a lo largo del libro la argumentación se estructura siguiendo tres líneas principales: $a$ ) la biografía de Estevan de Antuñano, contextualizada en el entorno político, económico, social y cultural de México de la primera mitad del siglo XIX; $b$ ) las redes por las que circuló Antuñano: las que heredó, primero de su familia biológica, luego de su familia política, y las que construyó él mismo en Veracruz, Puebla, la Ciudad de México y otros estados de la república; $c$ ) La cultura del personaje y sus ideas económicas, como sustrato de la evaluación que hizo de las sucesivas coyunturas político-económicas, a su vez fundamento de las decisiones empresariales tomadas.

Finalmente, y debido a la escasez de fuentes sobre momentos y procesos específicos en la vida y negocios de Antuñano, y nunca por falta de tesón e inteligencia de Evelyne Sanchez, subsisten importantes lagunas sobre la vida del biografiado. En particular, y tal como la autora deja entrever, el verdadero rol que jugó el suegro de Antuñano en la aventura textil poblana. No obstante, estamos ante un notable ejercicio historiográfico que no se deja encasillar: lo mismo es una historia social y cultural, que aporta a la construcción de las redes políticas en los albores de la nación mexicana y a la toma de decisiones económicas y el desarrollo de los negocios empresariales regionales. 